\title{
Comparative Study of Diatom Flora of Ganga River at Varanasi and Allahabad for Forensic Consideration
}

\author{
Madhavi Singh $^{1}$, A.K.Jain ${ }^{2}$, M.K.Mishra ${ }^{3}$, Vichar Mishra ${ }^{4}$ \\ ${ }^{I}$ (M.Sc. Student Deptt. Of Forensic Science Shiats, Allahabad, U.P. India) \\ ${ }_{2}^{2}$ (Professor Deptt. Of Forensic Science Shiats, Allahabad, U.P. India) \\ ${ }_{3}^{3}$ (Assistant Professor Deptt. Of Forensic Science Shiats, Allahabad, U.P. India) \\ ${ }^{4}$ (Ph.D.Scholar Deptt. Of Forensic Science Shiats, Allahabad, U.P. India)
}

\begin{abstract}
Diatoms are unicellular, autotrophic (photosynthetic) alga that has most distinctive features of crystalline extra cellular coat or frustules composed of silica and having unique patterns of symmetry and micro structure. They are found almost in aquatic environment including fresh and marine waters, soils, in fact anywhere in moist environment. For the identification and examination of diatom, total 40 water sample were collected from 10 different sites of Ganga River at Varanasi and Allahabad. After the analysis it was found that 22 diatom genera were recognised, in which 2 diatoms Actinocyclus sp., Triblionella sp. were peculiar in Varanasi and 1 diatom Cyclotella sp. was peculiar on Allahabad, 19 common species were identified in Varanasi and Allahabad. After analysis it's found that the population growths vary in winter and summer season at both places.
\end{abstract}

Keywords: Diatoms, population growth.

\section{Introduction}

Diatoms are unicellular, photosynthetic (autotrophic) alga that has most distinctive features of crystalline extra cellular coat or frustules composed of silica and having unique patterns of symmetry and micro structure. They are belonging to kingdom Protista and class Bacillariophyceae. There are more than 200 genera and 100,000 species of diatoms are known. Diatoms are microscopic eukaryotic organisms ranging in size approx 5 micron to 1000 microns and of the most common types of phytoplankton. The word 'Diatom' is derived from Greek word; dia = 'through' + temnein = 'to cut', i.e. 'cut in half' and diatom means "cut in two'. A special characteristic feature of diatom cell is that they are enclosed within a cell wall made up of silica (hydrated silicon dioxide) called frustules and is found almost aquatic environment including fresh and marine waters, soils, in fact anywhere moist environment. The species of diatoms either free floating, planktonic forms or attached to substrate, benthic forms that have $2 \mu \mathrm{m}$ to $1 \mu \mathrm{m}$ in size. Diatoms are unique Forensic marker in deciding the cause of death as drowning and dumping cases, when medical officer fail ascertain the cause of death especially in case when skeletonised and putrefied dead bodies are recovered, then diatom is very helpful for solving drowning cases.The medico-legal system in our country is active to discover the real truth behind instances of a person being murdered and then disposed in water bodies to stimulate drowning. In cases of death due to drowning the judiciary attributes as much importance to diatom test as DNA profiling. Detection of Diatoms from internal organs of victim of wet drowning is considered as a positive proof of ante mortem immersion by the forensic pathologists nationwide. The types of diatoms that are found in various body tissues/ organs are compared with those present in the putative (suspected) drowning medium. This further helps in the reconstruction of events that had occurred prior to the death of an individual. The presence of large number of diatoms of same species as that of putative drowning medium in the bone marrow of the deceased is used to confirm the cause of death as drowning.

\subsection{Collection of water sample}

\section{Methodology}

One important factor that should be taken into consideration before any sample processed is the cleanliness of bottle and glassware, especially if sample from several different sites are to be processed in the same laboratory.

$1000 \mathrm{ml}$ water samples was collected in neat and clean plastic bottles and after that bottles were tightly closed with cap and mention the location of sampling site, with date, time, and month respectively . Water sample were collected in the month of January, February March and April year 2016 continuously. Water sample were collected at the bank, mid \& across the river. The samples were collected from five different sites of Ganga River at Varanasi and Allahabad. 


\subsection{Extraction of Diatoms from water sample}

Water sample which was collected from different sites of the Varanasi and Allahabad of Ganga River were brought to the laboratory for extraction and isolation of diatom. Before extraction and identification of diatoms from water sample of various sites, all of the first we measure the $\mathrm{pH}$ of water sample with the help of digital $\mathrm{pH}$ meter. After that 2-3 drop of $2 \%$ formalin solution (as preservative to prevent further growth of diatoms) was added with the help of dropper and left as such for overnight. Next day sample was discarded in upper half amount and shaken vigorously and transfer it into a neat and clean (free from any contamination) glass beaker. Then added 2-5 drops of Lugol's iodine solution (settlement of diatoms in beaker) in water sample and beaker was covered with the help of brown paper and left as such overnight. Ludes et al., (1996). After settlement of water sample sediments were taken in a centrifuge tube with the help of dropper till the mark of centrifuge tube, and then centrifuge it at $1500 \mathrm{rpm}$ for 6-8 minutes by the help of centrifuge machine. After centrifugation pellet is obtained and supernatant was discarded. Again remaining sediments was taken in the centrifuged tube and this process repeat 3-4 times for obtained the pellets in more amount. After complete centrifugation in the obtained pellet mixed the Conc. Nitric acid 2-3 drops and fill the distilled water in centrifuge tube and mixed it and kept it 8-9 hrs without disturbance. After that pellet was washed with the help of distilled water through centrifugation process Tyagi et al., (1985), Pollanen (1998).

\subsection{Preparation of Microscopic slide}

For the examination of diatoms the microscopic slide were prepared by taken the pellets which was deposited at the bottom of centrifuge tube with the help of dropper and put it on microscopic slide. These slide are kept on hot plate at $25-35^{\circ} \mathrm{C}$ for 2-3 min. for drying. After that one drop of DPX put on slide covered it gently with the help of cover slip and fix the slide. After fixation of slide kept it on hot plate for one hr at 45$50^{\circ} \mathrm{C}$ temperature. Prepared slide were observed under microscope at $10 \mathrm{X}, 40 \mathrm{X}$ and $100 \mathrm{X}$ (oil immersion) magnification respectively. These same process were repeated for all sample Taylor $\boldsymbol{e t}$ al., (2007), Metzeltin $\boldsymbol{e t}$ al., (2005).

Identification of diatoms: After collection of sample and extraction and isolation of diatom from water sample, various type of diatom were identified by using standard different Online Data base and Data base of united state of diatom for identification. The diatoms were identified according to its raphe, striae, cell wall diameter, shaped and other morphological feature were examined.

\section{Results And Discussion}

Table 3.1The Diatom genera identified at all sites of Ganga River at Allahabad among months of January to April 2016.

\begin{tabular}{|l|l|l|l|}
\hline Sr. No. & Name of Diatom genera & Sr. No. & Name of Diatom genera \\
\hline 1 & Nitzschia sp. & 12 & Rhopalodia sp. \\
\hline 2 & Achnanthidium sp. & 13 & Melosera sp. \\
\hline 3 & Cyclotella sp. & 14 & Nupela sp. \\
\hline 4 & Fragilariforma sp. & 15 & Nitzschia sp. \\
\hline 5 & Fragilaria sp. & 16 & Fragilariforma sp. \\
\hline 6 & Aulacoseira sp. & 17 & Cyclotella sp. \\
\hline 7 & Synedra sp. & 18 & Fragilaria sp. \\
\hline 8 & Amphora sp. & 19 & Diploneis sp. \\
\hline 9 & Nitzschia sp. & 20 & Nitzschia sp. \\
\hline 10 & Cymbella sp. & 21 & Surirella sp. \\
\hline 11 & Amphora sp. & 22 & Melosira sp. \\
\hline
\end{tabular}

Table 3.2 The Diatom genera identified at all sites of Ganga River at Varanasi among months of January to April 2016.

\begin{tabular}{|l|l|l|l|}
\hline Sr. No. & Name of Diatom genera & Sr. No. & Name of Diatom genera \\
\hline $\mathbf{1}$ & Cyclotella sp. & $\mathbf{1 2}$ & Melosira sp. \\
\hline $\mathbf{2}$ & Nitzschia sp. & $\mathbf{1 3}$ & Nitzschia sp. \\
\hline $\mathbf{3}$ & Aulacoseria sp. & $\mathbf{1 4}$ & Pinnularia sp. \\
\hline $\mathbf{4}$ & Melosira sp. & $\mathbf{1 5}$ & Actinocyclus sp. \\
\hline $\mathbf{5}$ & Aneumastus sp. & $\mathbf{1 6}$ & Triblionella sp. \\
\hline $\mathbf{6}$ & Nitzschia sp. & $\mathbf{1 7}$ & Achnanthidium sp. \\
\hline $\mathbf{7}$ & Criticula sp. & $\mathbf{1 8}$ & Halamphora sp. \\
\hline $\mathbf{8}$ & Synedra spp. & $\mathbf{1 9}$ & Nitzschia sp. \\
\hline $\mathbf{9}$ & Achnanthidium sp. & $\mathbf{2 0}$ & Nitzschia sp. \\
\hline $\mathbf{1 0}$ & Surirella sp. & $\mathbf{2 1}$ & Cyclotella sp. \\
\hline $\mathbf{1 1}$. & Gomphophenia sp. & & \\
\hline
\end{tabular}


Table 3.3 Peculiar genera of diatom representing to Allahabad in relation to Varanasi.

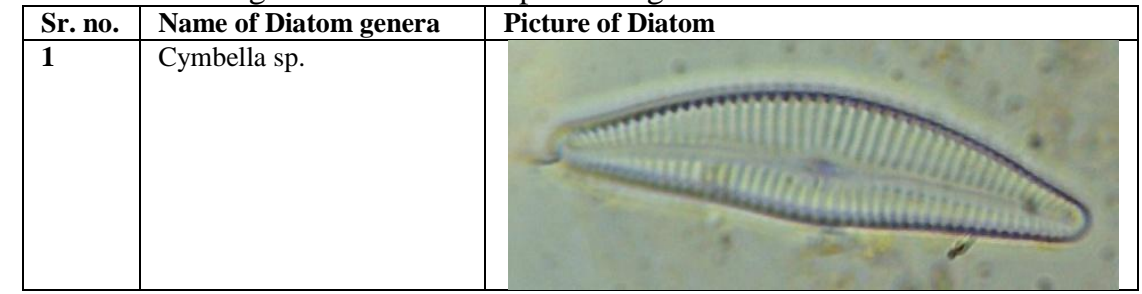

Table 3.4 Peculiar genera of diatom representing to Varanasi in relation to Allahabad.

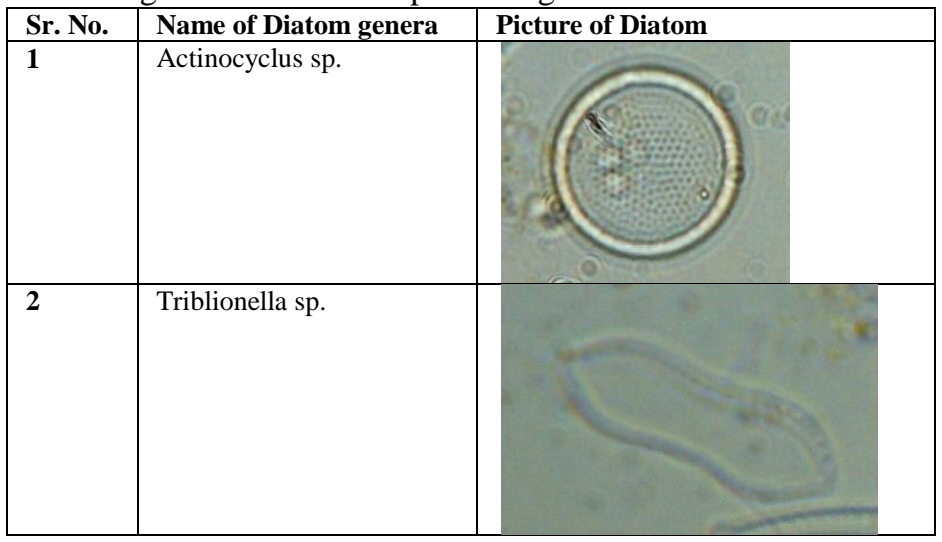

In the present study, 21 genera were identified in all sites of Ganga River at Allahabad while in Varanasi scenario 20 genera were identified in which species one was site specific at Allahabad and two were specific in Varanasi scenario. 18 species were common in Allahabad and Varanasi.

\section{Seasonal Variation to diatom}

Water samples were collected in two continuous season in the year $20161^{\text {st }}$ in winter season (month of January and February) and $2^{\text {nd }}$ in summer season (month of April) from 5 sites of Ganga River at Allahabad which is designated as A1 to A5 and 5 sites of Varanasi which is denoted as B1 to B5. The total 30 water samples were collected from the surface of different sites and fill in a 1 litre plastic bottle. The selected sites A1 to A5 and B1 to B5 include the river bank of Ganga River at Allahabad and Varanasi.

\section{Diatom cell count:}

Diatom cell were determined using Sedgwick Rafter chamber (Bernard, 1971) and were calculated by using following formula:

Diatom/Litre $(\mathrm{N})=\underline{\mathrm{n} \times \mathrm{v} \times 1000}$

$$
\text { V }
$$

Where, $\mathrm{n}=$ average number of diatom cells in $10 \mathrm{ml}$ of water sample

And $\mathrm{v}=$ volume of water sample in concentrated form $(\mathrm{ml})$

$\mathrm{V}=$ volume of total water (litre)

Table 3.5 List of diatom which was mostly found in winter season (year 2016) at all sites of Allahabad and Varanasi.

\begin{tabular}{|c|c|c|c|c|c|c|c|}
\hline \multirow[t]{2}{*}{ Sr. No. } & \multirow[t]{2}{*}{ Name of Diatom genera. } & \multicolumn{5}{|c|}{$\begin{array}{l}\text { Average no. of diatom observed in } \\
\text { three slides of each site of Allahabad }\end{array}$} & \multirow[t]{2}{*}{ Order of diatom } \\
\hline & & A1 & A2 & A3 & A4 & A5 & \\
\hline 1 & Nitzschia sp. & 7 & 9 & 8 & 7 & 29 & Pennales \\
\hline 2 & Achnanthidium sp. & 3 & 2 & 4 & 3 & 5 & Pennales \\
\hline 3 & Cyclotella sp. & 4 & 3 & 4 & 2 & 6 & Centrales \\
\hline 4 & Fragilariforma sp. & 1 & - & 2 & 1 & 3 & Pennales \\
\hline 5 & Fragilaria sp. & 4 & 2 & 5 & 3 & 4 & Pennales \\
\hline 6 & Aulucoseira sp. & 2 & 1 & 4 & 2 & 3 & Pennales \\
\hline 7 & Synedra sp. & 6 & 5 & 7 & 4 & 12 & Pennales \\
\hline 8 & Amphora sp. & 5 & 3 & 4 & 2 & 3 & Pennales \\
\hline 9 & Cymbella sp. & 1 & - & - & 1 & 2 & Pennales \\
\hline 10 & Rhopalodia sp. & 1 & 1 & 2 & 1 & 3 & Pennales \\
\hline 11 & Melosera sp. & 3 & 1 & 3 & 2 & 4 & Centrales \\
\hline
\end{tabular}




\begin{tabular}{|l|l|l|l|l|l|l|l|}
\hline 12 & Nupela sp. & 2 & 1 & - & 2 & - & Pennales \\
\hline 13 & Diploneis sp. & - & - & 2 & - & 1 & Centrales \\
\hline 14 & Surirella sp. & 3 & 1 & 4 & 2 & 6 & Pennales \\
\hline
\end{tabular}

*A1-Below Shastri bridge , A2-Near Arail Ghat, A3-Before $1 \mathrm{Km}$ confluencing of Sangam, A4-Near confluencing of Sangam, A5-Below Ajad Bridge.

\begin{tabular}{|l|l|l|l|l|l|l|l|l|}
\hline \multirow{2}{*}{ Sr. No. } & \multirow{2}{*}{ Name of Diatom genera. } & \multicolumn{6}{|c|}{$\begin{array}{l}\text { Average no. of diatom observed in } \\
\text { three slides of each site of Varanasi }\end{array}$} & \multirow{2}{*}{ Order of diatom } \\
\cline { 3 - 7 } & & B1 & B2 & B3 & B4 & B5 & \\
\hline 1 & Nitzschia sp. & 8 & 6 & 7 & 5 & 3 & Pennales \\
\hline 2 & Achnanthidium sp. & 4 & 3 & 4 & 2 & 6 & Pennales \\
\hline 3 & Cyclotella sp. & 3 & 1 & 2 & 3 & - & Centrales \\
\hline 4 & Fragilariforma sp. & 1 & 1 & 2 & 1 & 5 & Pennales \\
\hline 5 & Fragilaria sp. & 3 & 5 & 4 & 2 & 7 & Pennales \\
\hline 6 & Aulucoseira sp. & 2 & 1 & 4 & 2 & - & Pennales \\
\hline 7 & Synedra sp. & 5 & 3 & 6 & 8 & 1 & Pennales \\
\hline 8 & Amphora sp. & 5 & 4 & 4 & 2 & - & Pennales \\
\hline 9 & Cymbella sp. & 1 & - & - & 1 & - & Pennales \\
\hline 10 & Rhopalodia sp. & 1 & 1 & 2 & 1 & - & Pennales \\
\hline 11 & Melosera sp. & 3 & 1 & 3 & 2 & 2 & Centrales \\
\hline 12 & Nupela sp. & 2 & 1 & - & 2 & - & Pennales \\
\hline 13 & Diploneis sp. & - & - & 2 & - & - & Centrales \\
\hline 14 & Surirella sp. & 4 & 1 & 2 & 2 & - & Pennales \\
\hline 15 & Triblionella & 2 & 1 & 1 & 3 & - & Pennales \\
\hline
\end{tabular}

(-) sign shows that these type of diatom absent at that site.

*B1-Raj Ghat, B2-Manikarnika, B3-Dashaswamev Ghat, B4-Assi Ghat, B5-Ravidas Ghat.

Table 3.6 List of diatom which was mostly found in summer season at all sites of Allahabad and Varanasi.

\begin{tabular}{|l|l|l|l|l|l|l|l|l|}
\hline Sr. No. & Name of Diatom genera. & \multicolumn{6}{|c|}{$\begin{array}{l}\text { Average no. of diatom observed in } \\
\text { three slides of each site of Allahabad }\end{array}$} & \multirow{2}{*}{ Order of diatom } \\
\cline { 3 - 7 } & & $\mathbf{A 1}$ & $\mathbf{A 2}$ & $\mathbf{A 3}$ & $\mathbf{A 4}$ & $\mathbf{A 5}$ & \\
\hline 1 & Nitzschia sp. & 2 & 3 & 6 & 4 & 12 & Pennales \\
\hline 2 & Achnanthidium sp. & 1 & 7 & 2 & 5 & 3 & Pennales \\
\hline 3 & Cyclotella sp. & 9 & 18 & 8 & 19 & 42 & Centrales \\
\hline 4 & Fragilariforma sp. & 2 & 1 & 2 & 3 & 1 & Pennales \\
\hline 5 & Fragilaria sp. & 1 & - & 3 & 1 & 2 & Pennales \\
\hline 6 & Aulucoseira sp. & 5 & 7 & 4 & 6 & 10 & Pennales \\
\hline 7 & Synedra sp. & 2 & 1 & 2 & 3 & 5 & Pennales \\
\hline 8 & Amphora sp. & - & 1 & 2 & - & 1 & Pennales \\
\hline 9 & Cymbella sp. & 2 & 1 & 3 & 2 & 4 & Pennales \\
\hline 10 & Rhopalodia sp. & 1 & - & 3 & 1 & 2 & Pennales \\
\hline 11 & Melosera sp. & 2 & 4 & 1 & 2 & 4 & Centrales \\
\hline 12 & Nupela sp. & 1 & 1 & 1 & 1 & 2 & Pennales \\
\hline 13 & Diploneis sp. & - & 2 & 1 & 3 & 1 & Centrales \\
\hline 14 & Surirella sp. & 2 & 1 & 3 & 2 & 1 & Pennales \\
\hline
\end{tabular}

\begin{tabular}{|l|l|l|l|l|l|l|l|l|}
\hline Sr. No. & Name of Diatom genera. & \multicolumn{6}{|c|}{$\begin{array}{l}\text { Average no. of diatom observed in } \\
\text { three slides of each site of Varanasi }\end{array}$} & \\
\cline { 3 - 7 } & & B1 & B2 & B3 & B4 & B5 & \\
\hline 1 & Nitzschia sp. & 3 & 1 & 2 & 1 & 2 & Pennales \\
\hline 2 & Achnanthidium sp. & 4 & - & 1 & 1 & 2 & Pennales \\
\hline 3 & Cyclotella sp. & 10 & 8 & 9 & 11 & 4 & Centrales \\
\hline 4 & Fragilariforma sp. & 4 & 1 & 1 & 2 & - & Pennales \\
\hline 5 & Fragilaria sp. & 3 & 1 & 2 & 2 & 5 & Pennales \\
\hline 6 & Aulucoseira sp. & 2 & 4 & 3 & 4 & 3 & Pennales \\
\hline 7 & Synedra sp. & 2 & 1 & 2 & 3 & - & Pennales \\
\hline 8 & Amphora sp. & 1 & - & 2 & 2 & - & Pennales \\
\hline 9 & Cymbella sp. & 1 & - & - & - & - & Pennales \\
\hline 10 & Rhopalodia sp. & 3 & 1 & - & 2 & - & Pennales \\
\hline 11 & Melosera sp. & 5 & 2 & 4 & 3 & 4 & Centrales \\
\hline 12 & Nupela sp. & 2 & 1 & 1 & 2 & - & Pennales \\
\hline 13 & Diploneis sp. & 4 & 2 & - & 3 & - & Centrales \\
\hline 14 & Surirella sp. & 1 & - & 1 & 2 & 1 & Pennales \\
\hline 15 & Triblionella sp. & 6 & 2 & 4 & 3 & 1 & Pennales \\
\hline 16 & Actinocyclus sp. & 5 & 3 & 1 & 2 & 1 & Centrales \\
\hline
\end{tabular}




\section{Discussion}

Diatoms are highly microscopic unicellular, photosynthetic alga. They are generally found within water bodies. They have siliceous cell membrane. They play the most significant role in those cases, where the body is found that places which is for away from the actual site of drowning or dumping and after a long duration of submersion. This is so because diatoms are found in the long bones of the deceased specific to the site of drowning or struggling. In current scenario Diatom test is most useful technique in forensic science, this test is just like a land mark to solve the problem of drowning and dumping cases. It has the potential to provide an independent ecological assessment of trace evidence. This study presents identification of diatom and observed data to provide a preliminary evidence base in order to be able to understand the nature of diatom.

After completing the examination in this thesis, 41 diatoms had identified, in which 21 genera of Ganga River at Allahabad and 20 genera of diatom at Varanasi. Work can be discussed as according to work carried out by the Hurlimann et al., (2000) reported that one or more than one water sample should be taken from the site of drowning. Microscopicological test of diatom should record quantitative, qualitative and morphological details for every sample. Different type of diatoms were on the basis of their unique feature like that raphe, cell wall diameter and shape were examined for their identification, Metzeltin et al., (2005). In the present research different type of diatoms species were recognised according to their Raphe and cell shape.

In this thesis work total 41 diatoms were found in Ganga river at Allahabad and Varanasi scenario which shows the quite similar results of work done by Tiwari et al., (2006) and Mishra and Tripathi (2008). The diatom species shows the seasonal variation in different season, Vinayak et al., (2013). In this thesis work found the variation in the prominency of different diatom genera in different season.

\section{Conclusion}

From the present study we concluded that the alternation in diatom diversity at different sites of Ganga River at Allahabad and Varanasi region play the most significant role in the investigation of corpses which were obtained from the water bodies. Due to changes in seasonal variation we calculate the time since death. Diatom study can be useful in medico legal purposes to solve the cases of unclaimed drowned or dumped body like as DNA fingerprinting, as well as site correlation of doubtful cases. Diatom finding from the water as well as biological sample provide a lot of information about the cause of death, locality and probable season.

\section{References}

[1]. Krstic, Svetislav, Aleksej Duma, Biljana janevska, Zlatko Levkov, Ksenija Nikolova, Marina and Noveska (2002)Diatom in Forensic science Expertise of Drowning; A Mecodonian Experience. Forensic science International, 127(3): $198-203$.

[2]. Hurlimann J.,Feer P., Niederberger K., Dirnhofer R., and Wyler D.,(2000) Diatom detection in the diagnosis of death by drowning. International journal. Leg Med;114;6-14.

[3]. Tiwari, Ashesh and Chauhan S.V.S.(2006). Seasonal phytoplanktonic diversity of Yamuna. Journal Environmental Biology.27:3538.

[4]. Vinayak V, Mishra V, Goyal MK (2013) Diatom Fingerprinting to Ascertain Death in Drowning Cases. J Forensic Res 4: 207. 